\title{
IS WORKING CAPITAL MANAGEMENT IMPORTANT? EMPIRICAL EVIDENCE FROM MANUFACTURING COMPANIES IN GHANA
}

\section{Joseph Kwadwo Tuffour, John Adjei Boateng}

(1) School of Graduate Studies, University of Professional Studies, Accra, Ghana,

(2) School of Graduate Studies, University of Professional Studies, Accra, Ghana

Joseph Kwadwo Tuffour

School of Graduate Studies, University of Professional Studies,

Accra, Ghana

jktuffour@yahoo.co.uk

Article info

Paper category: Original Scientific Paper

Received: 27.3.2017.

Accepted: $27 \cdot 4 \cdot 2017$

JEL classification: C33, D22, L25 


\begin{abstract}
The objective of the study is to empirically examine the effect of working capital management on performance of manufacturing firms in Ghana. The study used six listed manufacturing companies on the Ghana Stock Exchange for the period 2008-2014. Correlation and regression analyses were used to analyze the effect of working capital management on manufacturing firms' performance. The study examines the effect of different components of working capital management on firm's performance. The study finds that the current ratio, average collection period and the accounts payable period have positive effect on profitability. However, only the current ratio has statistical significance. Also, while inventory conversion period as well as the cash conversion cycle have negative effect on performance, they are all statistically insignificant. It is recommended that finance managers should implement efficient and effective ways of managing working capital management. Emphasis should be placed on average payment period, improving sales growth and maintaining higher current ratio.
\end{abstract}

\title{
Keywords:
}

Working Capital Management, Return on Assets, Firm Performance, Manufacturing Companies, Ghana Stock Exchange 


\section{BACKGROUND OF THE STUDY}

In the immediate post-independence era, Ghana embarked on an import-substitution industrialization policy with the active involvement of the State. Currently, manufacturing constitutes about 6\% of Ghana's GDP (ISSER 2013) and provides employment for over 250,000 people (as at 2013). The manufacturing sub-sector grew at a rate of $2.2 \%$ in 2012 but drastically falling to a growth rate of $0.6 \%$ in 2013 . The development of the manufacturing sector was thus spearheaded by the State (in early post-independence) with support from multi-national companies. However, it was felt that the sustained growth of industries in Ghana would depend on one hand on working capital management. Several reforms have been made to this effort. This notwithstanding, the effort was marred with problems including lack of working capital, electricity, water and other related issues (Tuffour 2012; Tuffour, Barnor and Akuffo 2015). This influences the profit maximization of the manufacturing companies listed on the Ghana Stock Exchange.

Organizations, profit oriented or not, irrespective of size, type or nature of business, should have a certain quantity of working capital for day to day operations. Working capital is one of the most critical factors for sustaining liquidity, solvency, survival and profitability of most businesses (Mukhopadhyay 2004). The goal of working capital is to guarantee that companies have adequate cash flow to run regular operations and to reduce the possibility of not being able to meet short-term liabilities. According to Ranjith (2008), there is a tradeoff between risk and return in achieving the best level of working capital. This is because, though disproportionate investment in working capital makes a firm highly liquid, it also has the effect of reducing a firm's profitability. This optimal level is not simple to arrive at and it requires an efficient working capital management.

In manufacturing companies, holding excessive amounts of the various components of working capital will result in a firm losing out on the return on investment. Also, holding low amounts of working capital may result in certain shortages and failure of the organization to satisfy immediate obligations to the detriment of the overall performance of the organization (VanHorne and Wachowicz 2000). Working capital management aims at maintaining a best mix of the components of working capital. The management of working capital is embedded into the firm's strategy. This is to create value for shareholders (Raheman and Nasr 2007).

The general objective of any firm is to maximize profit. However, this cannot be achieved with insufficient liquidity for day-to-day operations, making the issue of liquidity very crucial to the organization. As a result there should be an equitable trade-off between two objectives. Without profit a firm may not be able to run for a long period, however without liquidity, insolvency and bankruptcy may bring the organization to a grinding halt (Raheman and Nasr 2007). Evidently, there are both internal and external issues which influence a firm's decision on how much current 
assets and current liabilities to keep. Kishore (2008) indicates that the level of working capital that various firms require differ in terms of the level of activity, company policy, market conditions, supply conditions, seasonality of operations, nature of business and so on.

Liquidity, which is determined by current assets and current liabilities, is importance in determining the financial strategies to be employed for efficient working capital management. Over time, cash conversion cycle is used to measure working capital management (Richardes and Laughlin 1980). The concept is that there is likely to be a strong link between the cash conversion cycle and profitability. Three different components of cash conversion cycle are identified: accounts payables, accounts receivables and inventory. For firms, these can be combined in different proportions to maximize profit (Choiu and Cheng 2006).

Also Moss and Stine (1993) proposed two dimensions: static and dynamic view to examine working capital. The static view as the name implies makes use of the traditional liquidity ratios such as current ratio to measure firm's liquidity at a particular point in time. The dynamic view considers cash conversion cycle. This is used to measure firm's liquidity.

This study uses the dynamic view of working capital management. The purpose of this study is to determine the effect of working capital on the profitability of selected manufacturing companies listed on the Ghana Stock Exchange (GSE). The study covers a sample of 6 selected manufacturing companies ${ }^{1}$ for the period covering 2008-2014. The choice of the six companies was done on two levels. The first involved clustering of the listed manufacturing companies. The second was based on the simple random selection of the companies from the clusters. The manufacturing firms listed on the Ghana Stock Exchange can be categorized into those related to a) households groceries and toiletries, b) metals, c) food and agriculture products, d) pharmaceuticals, e) paper products, f) breweries and g) information and communication technology. Thus, to capture a broad based representation, six of the categories were chosen. The study companies were then randomly selected from the chosen categories. In undertaking these, consideration was given to origin of the companies (i.e., whether they were initially Ghanaian or foreign owned), and the age of the companies in terms of period of enlistment. The focus on manufacturing companies stem from the basis that the firms have working capital in the form of cash, outstanding expenses, inventories, accounts receivables and payables. Unlike the financial institutions (banks and non-bank) which have bulk of their working capital in the form of cash, and will not be appropriate to provide better understanding on the topic under consideration.

The significance of the study is that Ghanaian businesses will be able to survive in the short-run and will be able to exist for longer periods if there is better under-

1 African Champion Industries Limited, Aluworks Ghana Limited, Cocoa Processing Company Limited, Pioneer Kitchenware Limited, PZ Cussons Ghana Limited and Unilever Ghana Limited. 
standing of the effect of working capital on profitability. Thus, businesses will become more profitable to all stakeholders especially the shareholders. The rest of the paper is structured as follows. The second section contains literature review which examines relevant theories on the issues and gives some insights on empirical works in the area of study. Section three is on the methodology used for the study. Section four contains the results and discussion of key findings while section five has conclusions and policy recommendations.

\section{LITERATURE REVIEW}

\subsection{Concept of Working Capital Management}

Working capital management is that area of finance that is concerned with ensuring adequate levels of current assets to meet current liabilities (Hampton 2007). The management of assets and liabilities concerns management of working capital (Khan and Jain 2007). Also, working capital management is an organization's ability to efficiently control current assets and current liabilities with a view of maximizing returns on its assets while minimizing the payment of its liabilities (Adelman and Marks 2007).

Furthermore, working capital management is concerned with a firm's decisions which determine the firm's composition of working capital. It refers to utilization of current assets namely: cash, account receivables, and inventory, and current liabilities: outstanding expenses, account payable, etc (VanHorne and Wachowicz 2008). This involves all those activities which concern the firm's receipts and payment of cash (Ross, Westerfield, Jaffe and Jordan 2008). Hofmann and Kotzap (2010) concluded that working capital management includes all aspects of the administration of current assets and liabilities.

The composition of working capital is always changing with respect to the phases of operations. Breadey, Myers and Marcus (2011) propose that net working capital is a better indicator of current assets and liabilities while cash conversion cycle is considered as effective and adequate indicator of working capital management. The introduction of cash conversion cycle approach by Hager (1976) as a dynamic method of measuring liquidity as against the traditional static liquidity ratios has received recommendation by Largay and Stickney (1980).

Brealey, Myers and Marcus (2011) viewed cash conversion cycle as "the longer the production process, the more cash the firm must keep tied up in inventories. Similarly, the longer it takes customers to pay their bills, the higher the value of accounts receivable. On the other hand, if a firm can delay payment for its own materials, it may reduce the amount of cash it needs. In other words, accounts payable reduce net working capital" (p. 181). Richards and Laughlin (1980) indicate that cash conversion cycle is the interval between the time of actual cash expenditure for pro- 
duction resources and the time cash is received from the sale of the product. This implies that if the time difference grows longer, then larger investments will have to be made into working capital (Deloof 2003). This reduces the firm's flexibility of cash for other activities (Khan and Jain 2007).

\subsection{Empirical Literature Review}

A study by Raheman and Nasr (2007) investigated the effect of different components of working capital management including average collection period, average payment period, cash conversion cycle, inventory turnover and current ratio on the net operating profit of firms in Pakistan. The findings indicated a negative relationship between the various components of working capital and profit.

Deloof (2003) researched the relationship between working capital management and profitability of non-financial firms over a five year period between 1992 and 1996. Using cash conversion cycle, inventory policy and trade credit policy as measures of working capital management, the conclusion was that if managers are able to reduce the number of days of accounts receipts and inventory conversion period, it would increase profit, proving there is a negative relationship between profitability and working capital management.

Also, Samiloglu and Demirgunes (2008) conducted a research on manufacturing firms in Turkey. They showed that account receivable period and inventory conversion period have significant negative effects on profitability. However, the research revealed cash conversion cycle has no significant effects on firm's profit. In addition, research works of Padachi (2006), Reheman and Nasr (2007), and GarciaTeruel and Martinez-Solano (2007) have all proven that in terms of cash conversion cycle it has significant negative relationship with firm's profitability.

Mohamad and Saad (2010) analyzed the effect of working capital management on the profitability of 172 firms over a five-year period (2003-2007) listed on Bursa Malaysia. They found negative relationship between working capital management components (cash conversion cycle, current liabilities to total asset ratio, current assets to current liability ratio and profitability captured by return on equity (ROE) and return on total asset (ROA). On the other hand, they also concluded that there is a significant positive relationship between the current assets to total assets ratio and firms' profit.

Gill, Biger and Mathur (2010) concluded that no significant relationship exists between inventory conversion period and firms profit. They were of the view that collection period of accounts receivables is most influencing factor among components of cash conversion. Thus, managers can generate value for shareholders by shortening the average collection period. As with Gill et al. (2010) study on manufacturing firms, Nobanee, Abdulatif and Al Hajjar (2011) examined the impact of cash conversion cycle on non-financial Japanese firms listed on the Tokyo Stock Exchange from 
1990 to 2004. The results showed that except for consumer goods and service sector, there is a negative relationship between the cash conversion cycle and the return on equity. Similar empirical findings have been obtained by Ebben and Johnson (2011).

Generally, the literature indicates that efficient working capital management leads to higher profitability. This research provides the empirical evidence of the relationship between working capital management and firm's profitability from selected manufacturing firms listed on the Ghana Stock Exchange.

\section{METHODOLOGY}

The study is based on the effect of working capital management on the profitability of listed manufacturing firms in Ghana. To achieve this objective, data was obtained from the annual financial reports and financial statements of the study companies from 2008 to 2014 as well as Ghana Stock Exchange. The study variables are based on literature. Table 1 contains the explanation of the variables.

Table 1.: Description of Variables

\begin{tabular}{|c|c|c|}
\hline SYMBOL & VARIABLE & DESCRIPTION \\
\hline \multicolumn{3}{|l|}{ Dependent variables } \\
\hline $\mathrm{ROA}$ & Return on Assets & Net Income/Total Asset \\
\hline \multicolumn{3}{|l|}{ Independent variables } \\
\hline ACP & Average Collection Period & (Account receivable/sales) $\times 365$ \\
\hline ICP & Inventory Conversion Period & $\begin{array}{r}\text { (Inventory/cost of goods sold) } \\
\text { x365 }\end{array}$ \\
\hline APP & Average Payment Period & $\begin{array}{r}\text { (Accounts payables/cost of goods } \\
\text { sold) } \times 365\end{array}$ \\
\hline CCC & Cash Conversion Cycle & $\mathrm{ACP}+\mathrm{ICP}-\mathrm{APP}$ \\
\hline \multicolumn{3}{|l|}{ Control variables } \\
\hline CR & Current Ratio & Current assets/current liabilities \\
\hline FL & Financial Leverage & Total debt/total assets \\
\hline SIZE & Firm Size & Natural log of total assets \\
\hline GROWTH & Growth in sales & (Salest-Salest-1)/Salest-1 \\
\hline FATA & Financial Asset to Total Asset & Financial Assets/Total Assets \\
\hline
\end{tabular}

Source: Authors' determination based on literature review

Given the determinants of ROA, then ROA = $\mathrm{f}(\mathrm{WC}, \mathrm{CV})$, where $\mathrm{WC}$ is working capital and $\mathrm{CV}$ is control variables. In a compact form, it implies these factors combine to determine the level of profitability.

The general form of the model is specified as:

$\mathrm{ROA}_{\mathrm{it}}=\beta_{\mathrm{o}}+\beta \mathrm{WC}_{\mathrm{it}}+\mathrm{\gamma CV}_{\mathrm{it}}+\varepsilon_{\mathrm{it}}$

where

$\mathrm{ROA}_{\mathrm{it}}$ is the Return on Asset of firm $i$ at time $t$ 
$\mathrm{B}_{\circ}$ : the intercept of the equation

$\beta$ : Coefficients of the working capital variables

$\mathrm{\gamma}$ : Coefficients of the control variables

$\mathrm{WC}_{\mathrm{it}}$ : the different variables for working capital management of firm $i$ at time $t$.

$\mathrm{CV}_{\mathrm{it}}$ : the different control variables determining profit of firm $i$ at time $t$.

t: time $=1,2, \ldots, 7$ years.

i: Manufacturing firms $=1,2, \ldots, 6$ firms.

$\varepsilon$ : error term.

This general model was converted to a specific form used by Usman, Saleem and Aziz (2012) which is presented as:

$\mathrm{ROA}_{\mathrm{it}}=\beta_{\circ}+\beta_{1}\left(\mathrm{WC}_{\mathrm{it}}\right)+\beta_{2}\left(\mathrm{SIZE}_{\mathrm{it}}\right)+\beta_{3}\left(\mathrm{FATA}_{\mathrm{it}}\right)+\beta_{4}\left(\mathrm{FL}_{\mathrm{it}}\right)+\beta_{5}\left(\mathrm{GROWTH}_{\mathrm{it}}\right)+\beta_{6}\left(\mathrm{CR}_{\mathrm{it}}\right)+\varepsilon_{\mathrm{it}}$

In the above model, $\mathrm{WC}_{\mathrm{it}}$ is measured by the following variables:

i. ACP (Average Collection Period)

ii. ICP (Inventory Collection Period)

iii. APP (Average Payment Period)

iv. CCG (Cash Conversion Cycle)

This model is re-specified using the four variables of working capital as follows:

Model 1: $\mathrm{ROA}_{\mathrm{it}}=\beta_{\mathrm{o}}+\beta_{1}\left(\mathrm{ACP}_{\mathrm{it}}\right)+\beta_{2}\left(\mathrm{SIZE}_{\mathrm{it}}\right)+\beta_{3}\left(\mathrm{FATA}_{\mathrm{it}}\right)+\beta_{4}\left(\mathrm{FL}_{\mathrm{it}}\right)+\beta_{5}\left(\mathrm{GROWTH}_{\mathrm{it}}\right)+\beta_{6}\left(\mathrm{CR}_{\mathrm{it}}\right)+\varepsilon_{\mathrm{it}}$ Model 2: $\mathrm{ROA}_{\mathrm{it}}=\beta_{\mathrm{o}}+\beta_{1}\left(\mathrm{CCC}_{\mathrm{it}}\right)+\beta_{2}\left(\mathrm{SIZE}_{\mathrm{it}}\right)+\beta_{3}\left(\mathrm{FATA}_{\mathrm{it}}\right)+\beta_{4}\left(\mathrm{FL}_{\mathrm{it}}\right)+\beta_{5}\left(\mathrm{GROWTH}_{\mathrm{it}}\right)+\beta_{6}\left(\mathrm{CR}_{\mathrm{it}}\right)+\varepsilon_{\mathrm{t}}$ Model 3: $\mathrm{ROA}_{\mathrm{it}}=\beta_{\mathrm{o}}+\beta_{1}\left(\mathrm{APP}_{\mathrm{it}}\right)+\beta_{2}\left(\mathrm{SIZE}_{\mathrm{it}}\right)+\beta_{3}\left(\mathrm{FATA}_{\mathrm{it}}\right)+\beta_{4}\left(\mathrm{FL}_{\mathrm{it}}\right)+\beta_{5}\left(\mathrm{GROWTH}_{\mathrm{it}}\right)+\beta_{6}\left(\mathrm{CR}_{\mathrm{it}}\right)+\varepsilon_{\mathrm{it}}$ Model 4: $\mathrm{ROA}_{\mathrm{it}}=\beta_{\circ}+\beta_{1}\left(\mathrm{ICP}_{\mathrm{it}}\right)+\beta_{2}\left(\mathrm{SIZE}_{\mathrm{it}}\right)+\beta_{3}\left(\mathrm{FATA}_{\mathrm{it}}\right)+\beta_{4}\left(\mathrm{FL}_{\mathrm{it}}\right)+\beta_{5}\left(\mathrm{GROWTH}_{\mathrm{it}}\right)+\beta_{6}\left(\mathrm{CR}_{\mathrm{it}}\right)+\varepsilon_{\mathrm{it}}$

The ACP, CCC, APP and ICP are the measures of working capital while the FATA, SIZE, FL, CR and GROWTH are control variables. The study presented three types of analyses: descriptive, correlation and pooled regression analyses. The models are to identify which working capital indicator has a relatively stronger influence in predicting the profit of a manufacturing company. To capture profitability, return on asset (ROA) is used according to literature.

\section{RESULTS AND DISCUSSION}

Three different components of the analyses are presented. These are descriptive, correlation and pooled regression analyses. Table 2 below contains the summary statistics of the data.

Table 2.: Summary Statistics

\begin{tabular}{|c|r|r|r|}
\hline \multicolumn{1}{|c|}{ Variable } & \multicolumn{1}{c|}{ Minimum } & \multicolumn{1}{c|}{ Maximum } & \multicolumn{2}{c|}{ Mean } \\
\hline ROA & -0.369 & 0.1717 & 0.0393 \\
CCC & -178.83 & 164.633 & -1.9217 \\
ACP & 0.7179 & 185.9701 & 68.523 \\
\hline
\end{tabular}




\begin{tabular}{|l|r|r|r|}
\hline \multicolumn{1}{|c|}{ Variable } & \multicolumn{1}{c|}{ Minimum } & \multicolumn{1}{c|}{ Maximum } & Mean \\
\hline ICP & 22.311 & 206.366 & 102.566 \\
SIZE & 10.725 & 19.125 & 14.923 \\
FATA & 0.014 & 0.442 & 0.1787 \\
FL & 0 & 0.6617 & 0.1371 \\
GROWTH & -0.342 & 0.975 & 0.1495 \\
APP & 24.93 & 373.742 & 173.011 \\
GR & 0.183 & 2.184 & 1.0517 \\
\hline
\end{tabular}

Source: Authors' calculation based on data from study organizations

Table 2 provides a summary of the descriptive statistics of the dependent and independent variables. It shows the average indicators of variables computed from the financial statements. The profitability rate, measured by the Return on Assets reveals an average of $3.93 \%$. The CCC has an average of -1.9217 . The value indicates that it takes the companies approximately 2 days to make expenditure for the purchases of raw materials and the collection of sales from finished goods. That is, the companies are taking less time to generate cash as compared to time required to make payments. The Inventory Conversion Period has an average of 102.57. This implies that the companies take approximately 102 days to sell their inventories within a year. The ACP also has average of 68.52. This indicates that it takes manufacturing companies approximately 68.5 days to collect their receivables in a year. On the other hand, it takes companies an average of 173 days to make payment for raw materials. These results have implications for ROA.

Linear regression model is based on the assumption that there is a linear relationship between the dependent variable and the independent variables. Thus, the existence of significant regression model is largely based on the existence of linear relationship between the dependent variable and each of the independent variables. A condition that can be problematic is multicollinearity, which can lead to misleading and inaccurate results. Multicollinearity occurs when there are high inter-correlations among some of the predictors or independent variables. The existence of collinearity means that two or more predictors contain much of the same information. In assessing the collinearity of the data, a Pearson correlation matrix of all the variables is computed. The correlation matrix of the data is presented in table 3 below.

Table 3.: Correlation Matrix

\begin{tabular}{|l|r|r|r|r|r|r|r|r|r|r|}
\hline & ROA & ACP & ICP & APP & CCC & CR & SIZE & FATA & FL & GROWTH \\
\hline ROA & 1.00 & & & & & & & & & \\
ACP & 0.093 & & & & & & & & & \\
ICP & 0.163 & 0.072 & & & & & & & & \\
APP & -0.157 & 0.578 & 0.099 & & & & & & & \\
CCC & 0.315 & 0.046 & 0.592 & -0.595 & & & & & & \\
\hline
\end{tabular}




\begin{tabular}{|l|r|r|r|r|r|r|r|r|r|r|}
\hline & \multicolumn{1}{|c|}{ ROA } & ACP & ICP & APP & CCC & CR & SIZE & FATA & FL & GROWTH \\
\hline CR & 0.586 & 0.0905 & 0.487 & -0.323 & 0.590 & & & & & \\
SIZE & -0.007 & 0.511 & 0.533 & 0.511 & 0.163 & 0.215 & & & & \\
FATA & 0.575 & 0.220 & 0.014 & -0.06 & 0.195 & 0.575 & -0.093 & & & \\
FL & -0.120 & 0.445 & 0.289 & 0.046 & 0.396 & 0.122 & 0.376 & -0.149 & & \\
GROWTH & 0.323 & 0.083 & 0.206 & 0.036 & 0.145 & 0.263 & 0.218 & 0.170 & 0.257 & 1.00 \\
\hline
\end{tabular}

Source: Authors' calculation based on data from study organizations

It can be observed from the correlation matrix (Table 3 and p-values indicated in appendixA) that CR, FATA, CCC and GROWTH each tends to have significant positive linear relationship with ROA, as indicated by their Pearson correlation coefficients (0.586, $0.575,0.315,0.323)$ and low probability values (0.000, $0.000,0.045$, 0.041 ) respectively which are all less than $5 \%$. These variables tend to have higher predictive influence on ROA than the rest of the independent variables. Observably, ACP and ICP have positive while APP has negative association with ROA.

Having established the extent of association between each independent variable and the ROA, pooled regression analysis is performed to examine the effect of the components of working capital on ROA.

The multiple correlation coefficient $(\mathrm{R})$ measures the relationship between the observed and predicted values of the dependent variable. Larger values of $\mathrm{R}$ indicate stronger relationships and vice versa. Model 1 produced an R figure of 0.881 (see table 4), indicating that the regression model between the dependent variable and the set of independent variables is appropriate. The adjusted R-square figure of 0.716 indicates that reliance on this model will account for $71.6 \%$ of the variations in the dependent variable. The second model produced an $\mathrm{R}$ figure of 0.892 , indicating the extent of correlation between the dependent variable and the set of independent variables. It also produced an adjusted R-square figure of 0.796 .

Again, model 3 produced R figure and adjusted R-square figure of 0.897 and 0.729 respectively. It indicates that the model is appropriate and its reliance can account for approximately $72 \%$ of the variations in the dependent variable. Finally, model 4 , has R figure and adjusted R-square figure of 0.881 and 0.717 respectively. These indicate that about $71.7 \%$ of the variation in the dependent variable is attributed to the set of explanatory variables.

The F-value, indicated by the ratio of regression mean square to the residual mean square shows the overall fit of the model. The analyses resulted in F-values of $13.296,12.304,10.774$ and 13.270 for models $1,2,3$ and 4, respectively with corresponding $p$-value of 0.000 for each. These confirm that the models are significantly reliable. That is, one can rely on the models to predict ROA with high accuracy. Having established that the models are appropriate and reliable, the next step is to estimate the pooled regression coefficients as indicated in table 4 , below. 
Table 4.: Regression Results

\begin{tabular}{|c|c|c|c|c|}
\hline Variable & $\begin{array}{c}\text { Model 1 } \\
\beta \text { (p-values) }\end{array}$ & $\begin{array}{c}\text { Model 2 } \\
\beta \text { (p-values) }\end{array}$ & $\begin{array}{c}\text { Model3 } \\
\beta \text { (p-values) }\end{array}$ & $\begin{array}{c}\text { Model } 4 \\
\beta \text { (p-values) }\end{array}$ \\
\hline Constant & $\begin{array}{r}-0.156 \\
(0.081)\end{array}$ & $\begin{array}{c}-0.198 \\
(0.013)\end{array}$ & $\begin{array}{l}-0.070 \\
(0.457)\end{array}$ & $\begin{array}{l}-0.224 \\
(0.017)\end{array}$ \\
\hline ACP & $\begin{array}{r}0.031 \\
(0.424)\end{array}$ & & & \\
\hline CCG & & $\begin{array}{l}-0.033 \\
(0.166)\end{array}$ & & \\
\hline APP & & & $\begin{array}{r}0.062 \\
\left(0.05^{8}\right)\end{array}$ & \\
\hline ICP & & & & $\begin{array}{l}-0.035 \\
(0.437)\end{array}$ \\
\hline SIZE & $\begin{array}{l}-0.006 \\
(0.335)\end{array}$ & $\begin{array}{l}-0.005 \\
(0.313)\end{array}$ & $\begin{array}{r}-0.020 \\
(0.049)\end{array}$ & $\begin{array}{l}0.0007 \\
(0.920)\end{array}$ \\
\hline FATA & $\begin{array}{r}0.322 \\
(0.153)\end{array}$ & $\begin{array}{r}0.292 \\
(0.147)\end{array}$ & $\begin{array}{c}0.092 \\
(0.697)\end{array}$ & $\begin{array}{r}0.368 \\
(0.065)\end{array}$ \\
\hline FL & $\begin{array}{l}-0.142 \\
(0.129)\end{array}$ & $\begin{array}{l}-0.05^{3} \\
\left(0.05^{3}\right)\end{array}$ & $\begin{array}{l}-0.079 \\
(0.287)\end{array}$ & $\begin{array}{r}-0.110 \\
(0.170)\end{array}$ \\
\hline GROWTH & $\begin{array}{r}0.082 \\
(0.087)\end{array}$ & $\begin{array}{r}0.066 \\
(0.145)\end{array}$ & $\begin{array}{r}0.075 \\
(0.087)\end{array}$ & $\begin{array}{l}0.074 \\
(0.112)\end{array}$ \\
\hline CR & $\begin{array}{l}0.1316 \\
(0.002)\end{array}$ & $\begin{array}{r}0.173 \\
(0.002)\end{array}$ & $\begin{array}{c}0.207 \\
(0.000)\end{array}$ & $\begin{array}{r}0.136 \\
(0.003)\end{array}$ \\
\hline Adjusted R2 & $0.7^{16}$ & 0.796 & 0.729 & 0.717 \\
\hline $\mathrm{F}$ & 13.296 & $12.3 \circ 4$ & 10.774 & 13.270 \\
\hline $\mathrm{R}$ & 0.881 & 0.892 & 0.897 & 0.881 \\
\hline $\operatorname{Sig}(F)$ & 0.000 & 0.000 & 0.000 & 0.000 \\
\hline
\end{tabular}

The values in parenthesis are $p$-values

Predictors: ACP, CCC, APP, ICP, SIZE, FATA, FL, GROWTH and CR

Dependent Variable: ROA

Source: Authors' calculation based on data from study organizations

The table contains regression coefficients with their corresponding $\mathrm{p}$-values to test the significance of each of the estimated regression coefficients. A significant coefficient indicates that the attached independent variable largely contributes to the significance of the overall regression model in explaining the variations in ROA. From the regression result (model 1 ), it is apparent that the Average Collection Period (ACP) has a co-efficient of 0.031 meaning a positive effect on profitability. However, its $p$-value of 0.424 implies that ACP has no statistical significance. This means the number of days a firm takes to collect its receivables has no effect on the profit of the firm. This result contradicts the findings of Samiloglu and Demirgunes (2008), and Deloof (2003) who found a negative relationship between ACP and profitability. However, Ramachandran and Janakiraman (2009) found a positive linkage. 
From Model 2, Cash Conversion Cycle (with a co-efficient of - o.o33) has negative effect on profitability. This inverse relationship makes economic sense, yet its p-value of o.166 implies CCC has no statistical significance in explaining ROA. This indicates that the time lag between purchases of raw materials and the collection of sales from finished goods does not significantly influence the profitability of manufacturing companies. This conclusion is consistent with the findings of Zariyawati, Anuuar and Abdul (2009). However, it contradicts the findings of Lyroudi and Lazaridis (2000) who found a positive relationship between CCC and profitability.

It is observed that Average Payment Period in the regression results (model 3), has a co-efficient of 0.062 implying that lengthening the payment period increases profitability. It means that companies with higher accounts payable period tend to have improved firm performance. The implication is that the longer a firm takes to make its payments to creditors, the higher the amount of working capital available which can be used to improve profitability. Also, its p-value indicates that this variable is significant. This result is in conformity with the findings of Usman, Saleem and Aziz (2012).

Also, the regression results (model 4) indicate that Inventory Conversion Period (ICP) has a coefficient of - 0.035 and $p$-value of 0.437 . This means ICP has no statistical significance on ROA. The implication is that the length it takes the companies to sell their inventories has no significant influence on ROA. In a similar research conducted by Garcia-Teruel and Martinez-Solano (2007) and Deloof (2003), it was concluded that inventory period has negative relationship with profitability.

The results from the entire four models suggest that Financial Asset to Total Asset (FATA) has no statistical significance on profitability because the $p$-values are all greater than 0.05 . That is, the ratio of Financial Asset to Total Asset has positive but insignificant effect on profitability except model 4 , which is significant at $10 \%$. This result is consistent with the findings of Samiloglu and Demirgunes (2008) who revealed that the financial asset to total asset ratio has no statistical significance on profitability. Also financial leverage (FL) is negative but insignificant in all the models except model 2 which is significant at $10 \%$. This means changing the levels of leverage has no significant effect on firms' profit.

Surprisingly, firm size (SIZE) has an unusual behavior. It has no significant effect on profitability in all four models except model 3. Also, it is negatively related to ROA in all models except in model 4 . This is an indication of the fact that larger companies are not necessarily more profitable than smaller companies. Change in sales (Growth), is statistically significant at 10\% level in models 1 and 3. This may be due to very high selling expenses such as advertising and promotional activities which offset the increase in sales.

Current Ratio (CR) has statistical significance and direct effect on ROA in all models. The implication is that companies with higher current assets to current liabilities ratio are more likely to have higher profit. Thus, this result is consistent with the findings of Raheman and Nasr (2007). 


\section{CONCLUSION AND POLICY IMPLICATIONS}

The research used four different measures of working capital to ascertain the extent to which working capital management influences profitability of selected manufacturing companies listed on the Ghana Stock Exchange over the 2008-2014 period. The empirical results indicate that firms' financial leverage, cash conversion cycle and inventory conversion period have negative effect on ROA, the profitability indicator. On the other hand, financial asset to total asset ratio, Average Collection Period, Average Payment Period, growth and current ratio have positive impact on profitability. Irrespective of the nature of the relationship, the various measures of working capital, that is ACP, CCG and ICP have no statistical significance on profitability except APP.

The above findings indicate clearly that three measures of working capital employed in this research have no significant effect on profitability. However, this conclusion does not dispute the fact that working capital management practices are important. The conclusion is rather an indication of the fact that regardless of the policies adopted by manufacturing companies in the management of working capital, it has not been significant in improving profitability. It is recommended that manufacturing companies in Ghana should adopt working capital management policies that will keep working capital at optimum level. Generally, over the study period, working capital management has not been effective for the manufacturing industry in Ghana in contributing to the growth in profit. Emphasis should be placed on average payment period, improving sales growth and maintaining higher current ratio.

Based on these results, the next steps in respect of further research directions would be to build stronger overall evidence by analyzing working capital issue from the perspective of different types of companies in Ghana as well as determining the appropriate optimal level of working capital to sustain firm operations. Although this research was carefully prepared and has reached its objectives, its limitation is the small number of companies used. A relatively larger number of firms would be better to generalize results. Also, the study was limited by the relatively short period. Effort to obtain data in forms other than annual series might give useful results. 


\section{REFERENCES}

Adelman, P. J., and Marks, A. M. Entrepreneurial finance, $4^{\text {th }}$ ed. New Jersey: Pearson, Prentice Hall, 2007.

Brealey, R., Myers, S, and Allen, F. Fundamentals of corporatefinance, $3^{\text {rd }}$ ed. Boston: McGraw-Hill Primis Custom Publishing, 2011.

Chiou, J., and Cheng, L. "The Determinants of Working Capital Management." Journal of American Academy of Business, 10(1), (2006): 149-155

Deloof, M. "Does Working Capital Management Affect Profitability of Belgian Firms? Business Finance and Accounting Journal, $3 \circ$ (3 and 4), (2003): $57^{3}-5^{8} 7$

Ebben, J. J., and Johnson, A. C. "Cash Conversion Cycle Management in Small Firms: Relationships with Liquidity, Invested Capital and Firm Performance." Journal of Small Business and Entrepreneurship, 24(3), (2011): $381-416$

Garcia-Teruel, P. J., and Martinez-Solano, P. "Effects of Working Capital Management on SME Profitability." International Journal of Managerial Finance, 3(2), (2007): 164-177

Gill, A., Biger, N., and Mathur, N. "The relationship between working capital management and profitability: Evidence from the United States." Business and Economics Journal, (2010): 10, 1-9

Hager, H. C. "Cash management and the cash cycle." Management Accounting, 57; (1976): 78-79

Hampton, J. J. Financial decision making, concepts, problems and cases, $4^{\text {th }}$ ed. New Delhi: Prentice Hall of India Private Limited, 2007.

Hofman, E., and Kotzab, H. “A supply chain-oriented approach of working capital management." Journal of Business Logistics, 31(2), 2010.

Institute of Statistical, Social and Economic Research. The state of Ghanaian economy. Sundel Services, Accra, 2014.

Khan, M., and Jain, P. K. Management accounting: Text, problems and causes, $4^{\text {th }}$ ed. New Delhi: Tata McGraw-Hill, 2007.

Kishore, R. M. Taxmann's financial management. $6^{\text {th }}$ ed. New Delhi: Taxmann Allied Services, 2008.

Largay, J. A., and Stickney, C. P. "Cash flows, ratio analysis and the W. T. Grant Company Bankruptcy." Financial Analysts Journal, (1980):51-54

Lyroudi, K., and Lazaridis, Y. "The cash conversion cycle and liquidity: Analysis of food industry in Greece." Research Journal of Business Management, 7 (4), (2000):1-57

Mohamad, N. E., and Saad, N. B. "Working capital management: The effect of market valuation and profitability in Malaysia." International Journal of Business and Management, 5(11), (2010):14,0-147

Moss, J., and Stine, B. "Cash conversion cycle and firm size: A study of retail firms." International Journal of Business and Management, 19 (8), (1993): 25-35

Mukhopadhyay, D. "Working capital management in heavy engineering firms - A case study."

International Journal of Business and Management, retrieved from myicwai.com/knowledgebank/fm4.8. (2004)

Nobanee, H., Abdullatif, M., and Hajjar, M. "Cash conversion cycle and firm's performance of Japanese firms." Asian Review of Accounting, 19 (2), (2011): 147-156

Padachi, K. "Trends in working capital management and its impact on firms' performance." International 
Review of Business Research Paper, 2(2), (2006):45-58

Raheman, A., and Nasr, M. "Working capital management and profitability-Case of Pakistani firms." International Review of Business Research Paper, 3(1), (2007): 279-300

Ranjith, A. B. A. "The impact of firms' capital expenditure on working capital management: An empirical study across industries in Thailand." International Management Review, $4(1),(2008): 11-24$

Richards, V. D., and Laughlin, E. J. "A cash conversion cycle approach to liquidity analysis." Financial Management, $9(1),(1980): 32-38$

Ross, S. A., Westerfield, R. W., Jaffe, J., and Jordan, B. D. Modern financial management. $8^{\text {th }}$ ed. McGrawHill International Edition, 2008.

Samiloglu, F., and Demirgunes, K. "The effect of working capital management on firm profitability: Evidence from Turkey." The International Journal of Applied Economics and Finance, 2(1), (2008): 44-55

Tuffour, J. K. "Analysis of the effect of external debt on private investment crowding-out in Ghana." Journal of Business Research, 6(1 and 2), (2012): 73-83

Tuffour, J. K., Barnor, C., and Akuffo, E. "Do leadership styles matter in microfinance performance? Empirical evidence from Ghana." Journal of Business Research, 9, (2015)

Usman, J. K., Saleem, F. A., and Aziz, H. A.International Conference on Statistical Sciences Lahore. Pakistan, July $5^{-6},(2012): 289-302$

VanHorne, J. C., and Wachowicz, J. M. Fundamentals of financial management. $13^{\text {th }}$ ed, London: Pearson Education Limited. 2008.

Zariyawati, M. A., Annuar, M. N., and Abdul-Rahim, A. S. "Effect of working capital management on profitability of firms in Malaysia." Journal of Cash Management, 17, (2009): 51-57 


\section{APPENDIXA}

\begin{tabular}{|l|c|c|c|c|c|c|c|c|c|c|}
\hline & ROA & ACP & ICP & APP & CCG & CR & SIZE & FATA & FL & GROWTH \\
\hline ROA & & & & & & & & & & \\
ACP & 0.312 & & & & & & & & & \\
ICP & 0.195 & $0.35^{3}$ & & & & & & & & \\
APP & 0.203 & 0.000 & 0.302 & & & & & & & \\
CGC & 0.045 & 0.405 & 0.000 & 0.000 & & & & & & \\
GR & 0.000 & 0.309 & 0.003 & 0.041 & 0.000 & & & & & \\
SIZE & 0.485 & 0.002 & 0.000 & 0.000 & 0.194 & 0.127 & & & & \\
FATA & 0.000 & 0.121 & 0.470 & 0.376 & 0.151 & 0.000 & 0.313 & & & \\
FL & 0.264 & 0.007 & 0.061 & 0.405 & 0.015 & 0.260 & 0.020 & 0.216 & & \\
GROWTH & 0.041 & 0.331 & 0.138 & 0.425 & 0.222 & 0.080 & 0.123 & 0.185 & 0.085 & \\
\hline
\end{tabular}

